\title{
The Russian ETF puzzle and its possible reasons
}

\author{
Evgeni B. Tarassov* \\ Department of Finance, Head of Wealth Management Institute, National Research University \\ Higher School of Economics, Moscow, Russia
}

\begin{abstract}
This paper documents the Russian exchange-traded funds (ETF) puzzle. Since 2014-2015, most Russian fund-offunds have been investing only in one preselected Western ETF. During that period, these funds have raised more money than any other fund category in Russia. However, if an investor buys shares in an ETF via a mutual fund (MF) rather than doing it directly, she overpays up to $36 \%$ of the invested capital over a 10-year horizon. Additionally, the paper provides a brief overview of possible reasons for this anomalous, suboptimal index investing behavior, and formulates hypotheses for further research.
\end{abstract}

Keywords: ETF, index fund rationality paradox, non-optimal index investing, index mutual funds

JEL: G02, G 11

\section{Introduction}

Exchange-traded funds (ETF) have reached impressive levels in many markets: the annual trade volume is 16 trillion USD in US and 518 billion USD in China. Russia is still among the countries where the annual volume of domestic ETF trades is below one million USD. On the other hand, foreign ETF have become a popular investment target among the Russian mutual fund (MF) industry. Unlike other countries, where people invest in ETF directly, Russian investors do it via domestic MF. I have not found similar practices in other countries.

The MF "Sberbank Biotechnology", which invests only in iShares Nasdaq Biotechnology ETF, was created at the end of May 2015. In August of the same year, it joined the list of the five largest Russian MFs. The success story of the next largest fund, "Raiffeisen

\footnotetext{
${ }^{*}$ Corresponding author: Evgeni B. Tarassov, Department of Finance, Head of Wealth Management Institute, National Research University Higher School of Economics, 26 Shabolovka, 119049, Moscow, Russia. Tel.: +7 92577264 25; E-mail: tarassov.evgeni@gmail.com.
}

USA", which invests only in SPDR S\&P 500 ETF TRUST, is also exceptional. It doubled its Net Asset Value (NAV) during the winter 2014-2015. Between 2014 and 2015, the group "funds of funds" has raised more money than any other category of funds in Russia (Appendix 1). During the same period, most Russian funds of funds changed their investment strategy completely: since 2014 most of them have been investing only in one preselected western ETF out of the world top 100 list (Appendix 2).

The calculations in section 2 demonstrate that investing for 10 years in an ETF via a Russian fund of funds, the investor pays up to $36 \%$ of invested capital more (in commission) than if she invests in the same ETF directly. Most financial institutions that own the management companies also own brokerage services where clients could buy these ETF directly. For clients above 10000 USD most brokerage companies offer an individual support service including the technical (logistical) coaching for those who are still not comfortable with advanced technologies.

The Russian ETF puzzle seems to be a natural experiment showing another example of the index 
fund rationality paradox (Boldin and Cici, 2010). Over the last 20 years, literature has emerged investigating why individual investors invest in index funds with higher commissions while there are MF tracking the same index charging much lower commissions (Hortacsu and Syverson, 2004; Elton, Gruber, and Busse, 2004; Collins, 2005; Bergstresser, Chalmers, and Tufano, 2009; Boldin and Cici, 2010; Choi, Laibson, and Madrian; 2010).

Hortacsu and Syverson (2004) found that the main reason for this phenomenon is search costs. Collins (2005) argued that index funds are not commodity products because funds provide various additional services for the investors. Bergstresser et al. (2009) found a positive correlation between new money inflow and the level of sales compensation. However, Choi et al. (2010) demonstrated that investors do not recognize that index mutual funds are commodity products even if search costs, any services, and the direct influence of a sales person are excluded. The level of the participants' financial literacy in this study was far above that of the average American investor. Additionally, one of the groups received the description of the index funds' working principles. Despite this support, most participants still chose the index funds with high commissions.

Besides documenting the Russian ETF puzzle, this paper provides a brief overview of its possible reasons, including the reasons for index fund rationality paradox itself.

The article has the following structure. The second section presents the model and the calculations that demonstrate the Russian ETF puzzle. The third section discusses its possible reasons and formulates hypotheses for further research. The history of ETF, working mechanisms, a literature review and research perspectives may be found in Tarassov (2016).

\section{The model and the calculation}

The model below compares the costs of investing in ETF via a MF or directly. All the costs that are common for investing via a MF and directly are not included in the model; it takes into account only the costs that differ. This model is similar to (Kostovetsky, 2003) which compares the costs of investing in an index via a MF or via an ETF. The following costs are identical for investing in an ETF via a MF or directly:

- Taxes: a Russian based investor pays the same capital gain and dividend taxes on revenues from any kind of securities;
- Transfer costs: they are zero if money is put directly into the account of either a management company or a discount broker (for investing in any securities directly);

- The ETF expenses itself (management fee, spread, premium, custody etc.).

Regarding liquidity, it is obvious that the liquidity level of a TOP 100 world ETF is not lower than that of a Russian based MF investing in that ETF. I assume that the management companies of Russian funds transfer all the money received from their customers immediately into the ETF. Therefore, we do not need to compare the performance of the ETF itself and that of the MF investing in this ETF.

In the model, I also ignore possible fluctuations in the MF unit price after an investor has asked the fund to buy her units back. Leading Russian management companies reserve up to 10 working days to pay their clients after they decided to sell their units.

Based on these simplifications I used the following model:

$$
X=Y / S
$$

$X$ is the amount (the share of the capital invested) an investor overpays if she invests in ETF via a MF rather than directly.

$Y$ is the difference between expenses using MF and a discount broker account for investing in the same ETF,

$$
Y=M F c-B c ;
$$

$M F c$ (Mutual Fund cost) are the costs of investing via $\mathrm{MF}$,

$$
M F c=F c+V d+V s
$$

Fc (Fixed cost) are management fees, custody, audit and other fund expenditure,

$V d$ (variable cost days) are costs depending how many days an investor holds the fund units,

Vs (variable sum) are costs depending on the amount of the capital invested;

$B c$ (broker cost) are costs of owning a discount broker account and using it to trade securities;

$S$ is the amount of the capital invested.

\subsection{The calculation}

Details on the data and the calculation are given in Appendix 3; here I report the main results. The 
Table 1

The costs of investing in ETF via MF, March 2016. Example: invested capital three ${ }^{\mathrm{a}}$ million rubles

\begin{tabular}{|c|c|c|c|c|c|c|}
\hline \multirow{2}{*}{$\begin{array}{l}\text { Expenses, \% } \\
\text { Investment period (years) }\end{array}$} & \multicolumn{2}{|c|}{ Raiffeisenbank } & \multicolumn{2}{|c|}{ Sberbank } & \multicolumn{2}{|c|}{$\begin{array}{c}\text { Sberbank mutual } \\
\text { fund selling via } \\
\text { Citibank }^{\mathrm{b}}\end{array}$} \\
\hline & 1 & $3+1$ day & 1 & $3+1$ day & 1 & $3+1$ day \\
\hline \multicolumn{7}{|l|}{ Annual $(F c), \%$} \\
\hline Management fees & 2.4 & 7.2 & 2.0 & 6.0 & 2.0 & 6.0 \\
\hline Custody/audit & 0.6 & 1.8 & 0.2 & 0.6 & 0.2 & 0.6 \\
\hline Other expenditure & 0.6 & 1.8 & 0.5 & 1.5 & 0.5 & 1.5 \\
\hline \multicolumn{7}{|l|}{ One time fee, \% } \\
\hline$>3$ million rubles $(V s)$ & 0 & 0 & 0.5 & 0.5 & 1.25 & 1.25 \\
\hline$>181 ;<732$ days $(V d)$ & 2.0 & & 1.0 & & 3.0 & \\
\hline$>1095(V d)$ & & 0 & & 0 & & 3.0 \\
\hline Total, $\%$ of the capital invested & 5.6 & 10.8 & 4.2 & 8.6 & 6.95 & 12.25 \\
\hline Total, rubles (000 s) & 168 & 324 & 126 & 258 & 209 & 368 \\
\hline
\end{tabular}

Source: created by the author based on http://sberbank.ru/ru/person/sbpremier/products/invest/pif; http://www.raiffeisen.ru/retail/deposit_investing/funds/. ${ }^{a}$ The minimum amount to invest in Raiffeisenbank mutual funds is 3 million rubles (ca. 50 thousand USD in 2015). ${ }^{\mathrm{b}} \mathrm{A}$ rare case of selling mutual funds via other bank.

data come from the leading fund management companies of Sberbank and Raiffeisenbank. ${ }^{1}$ (Tables 1 and 2).

Expenses for investing via a discount broker account $(\mathrm{Bc})$ are around $0.1-0.2 \%$. While one may need to have at least 10000 USD in order to open an account with a western broker, 100 USD is be enough to open an account within a Russian one.

\subsection{The calculation result}

As shown in Appendix 4, if $B c$ is subtracted, the overpaying sum, $X$, ranges from $4 \%$ to $7 \%$ of capital invested for a one-year investment, from $14 \%$ to $18 \%$ for a five-year investment, and from $27 \%$ to $36 \%$ for a ten-year investment.

\section{Brief overview of possible reasons for the Russian ETF puzzle and hypotheses for further research}

In order to come up with plausible hypotheses for the further research into the reasons for the nonoptimal index-investing phenomenon in general, and the reasons for the Russian ETF puzzle in particular, I conducted brief interviews with fifteen experts. Among the experts were four HNWI (high net worth individuals), one cognitive psychology professor, and six finance and economics professors as well as four $\mathrm{PhD}$ students with extensive work experience in

\footnotetext{
${ }^{1}$ National League of Management Companies. http://www.nlu. $\mathrm{ru} /$ pifs-scha.htm?tab=tab $1 \&$ pageNo $=0 \& \mathrm{~s}=1 \& \mathrm{~b}=0 \&$ searchdate $=$ 31.12.2015\&t=all\&c=\%D4
}

Table 2

Additional information about MF expenses (Vs+Vd), as a percentage of the capital invested, March 2016

\begin{tabular}{lcccc}
\hline Invested period (days) & $<181$ & $<732$ & $<1095$ & $>1095$ \\
\hline $\begin{array}{l}\text { Raiffeisenbank } \\
\quad>3 \text { million rubles }\end{array}$ & 2 & 2 & 1 & 0 \\
$\begin{array}{l}\text { Sberbank } \\
\quad>3 \text { million rubles }\end{array}$ & 2.5 & 1.5 & 0.5 & 0.5 \\
$\quad<3$ million rubles & 3 & 2 & 1 & 1 \\
$\begin{array}{l}\text { Citibank } \\
\quad<1 \text { million rubles }\end{array}$ & 4.5 & 4.5 & 4.5 & 4.5 \\
$\quad<5$ million rubles & 4.25 & 4.25 & 4.25 & 4.25 \\
$>5$ million rubles & 4 & 4 & 4 & 4 \\
\hline
\end{tabular}

Source: created by the author based on http://sberbank.ru/ru/ person/sbpremier/products/invest/pif; http://www.raiffeisen.ru/ retail/deposit_investing/funds/. ${ }^{\text {a }}$ The minimum amount to invest in Raiffeisenbank mutual funds is 3 million rubles (ca. 50 thousand USD in 2015).

finance. Main results and key points from two interviews with experts who invested in these funds are in Appendix 3.

Based on the insight of the interviews and discussions held at National Research University Higher School of Economics (HSE), I formulated six hypotheses for possible reasons why Russian investors buy ETF via MF rather doing this directly:

1. search costs;

2. trust;

3. MF having additional services;

4. the interdiction of investing in foreign stock if not obtained a qualified investor status (in Russia since 2015);

5. a predisposition to categorical thinking/ stereotyping;

6. a low level of index investing culture. 
Hypothesis 1. Hortacsu and Syverson (2004) argue that the main reason for non-optimal behavior in index investing is search costs. However, their observation period finished in 2000. Since then, internet searching has become much more popular. This important change has reduced search costs. In Russia, a search question in any of the main search engines such as google shows highly reputable organizations offering ETFs directly. Additionally, all major banks that offer MF investments in one ETF also offer discount broker services which provide investors with possibilities to buy these ETFs directly. It is a separate question whether to include in search costs the mental energy of asking what an ETF is and what the ways to invest in one is, after having received an offer to invest in a MF that invests in an ETF. However, even if the search costs are an important reason for the existence of the Russian ETF puzzle, Choi at al. (2010) demonstrate that many people make irrational choices in index investing even when there are no search costs at all.

Hypothesis 2. This hypothesis suggests that because of regular financial storms in the Russian financial sector, people prefer to trust their money mostly to an organization with a good reputation. However, this argument is weak since an investor may buy an ETF directly or via a MF using the same financial institution.

Hypothesis 3. MF provide additional service for their clients. For example, tax declaration or international diversification. This hypothesis is in line with Collins (2005) who argues that index funds are not commodity products because of the different level of additional services they provide. However, Elton et al. (2004) show that there is no correlation between new money inflow and the level of the fund services.

In Russia, if an individual decides to invest in any foreign assets she has to make an additional tax declaration regarding these assets. Buying mutual fund units does not require such a declaration as the mutual fund units are Russian assets. Additionally, MF are tax agents themselves and take care of the client's taxes by calculating and paying them directly to the authorities. This hypothesis says that clients are ready to pay higher commissions to a MF rather than invest directly in an ETF directly because they prefer to avoid any additional contact with tax authorities. In a survey of investors (Tarassov, 2017b), the participants were asked whether "by investing for 5 years in a foreign ETF they would prefer to do it directly or via a Russian MF that would take 150000 rubles in commission from a 1000000 ruble investment. Investing via a MF means avoiding any contact with tax authority regarding declaration of foreign assets". No one answered that she would prefer investing via a MF.

In regards to international diversification, the majority of Russian residents use foreign currency bank deposits (Table 3).

Hypothesis 4. The Russian ETF puzzle exists due to the foreign asset investment interdiction for non-qualified investors (since 2015). This reason has also limited validity as, first, one of the market leaders, Raiffeisenbank, sells mutual fund units from 3 million rubles (ca. 50 thousand USD in 2015). Most people who would like to invest 3 million rubles in MF have another 3 million in other financial assets enough to receive the status of qualified investor. Second, the boom for funds of funds already existed in 2014 , that is before the status requirement.

Hypothesis 5. It is possible that the main reason for non-optimal index-investing in general, is people's predisposition to categorical thinking or stereotyping: an individual investor puts these funds into the same category as actively managed funds so the commission of $2-3 \%$ does not raises any questions. Research testing this hypothesis is in its final stage (Tarassov, 2017b).

Hypothesis 6. One phrase, used during the interviews, "people do not know what an ETF means and prefer to invest in everything using the old methods

Table 3

Russian household's bank deposits and the funds of funds NAV (the largest international diversification alternative for investing in foreign securities via a Russian based financial institution), million rubles

\begin{tabular}{lcccc}
\hline Year & 2012 & 2013 & 2014 & 2015 \\
\hline Ruble bank deposits & 10956237 & 13236389 & 13784044 & 15197829 \\
Foreign currency bank deposits (shown in rubles) & 2478000 & 3024405 & 4303032 & 5994987 \\
Funds of funds (NAV) & 2560 & 2734 & 14272 & 17129 \\
\hline
\end{tabular}

Sources: created by the author based on data of Russian Central Bank and National League of Management Companies, January 2016. 
Table 4

NAV of index funds*, NAV of all open-end MF, saving accounts (individual investors), Russia, billion rubles (31.12.2013)

\begin{tabular}{lc}
\hline Financial instrument & NAV \\
\hline MF index* & 3 \\
MF open-end & 113 \\
Bank deposits, in rubles & 15197 \\
Bank deposits, in foreign currency (shown in rubles) & 5994 \\
\hline
\end{tabular}

*Prior to March 2016, there were no ETF in the Russian equity market. Sources: created by the author based on data of National League of Management Companies and Russian Central Bank.

Table 5

NAV of index fund (MF and $\mathrm{ETF}^{*}$ ), NAV of all open-end MF, saving accounts (individual investors), USA, trillion USD (31.12.2013)

\begin{tabular}{lr}
\hline Financial Instruments & NAV \\
\hline MF index & 1,73 \\
ETF* & 1,68 \\
MF open-end & 11,54 \\
Saving accounts & 7,40 \\
\hline
\end{tabular}

* $99 \%$ of ETF (weighted) passively track a preselected index (Deutsche Bank ETF industry annual report 2014). Sources: created by the author based on data of the Federal Reserves, Investment Company Institute (factbook 2015), and Deutsche Bank (ETF annual report 2014).

- a mutual fund", triggered the idea for research into index investing culture. Taking into consideration the relatively substantial losses of Russian investors, I believe that it is important investigate Russia-specific reasons further. For example, $4 \%$ (minimum excess commission for one year holding) of 17 billion (NAV of funds of funds $)^{2}$ is 680 million rubles which is paid in unnecessary commissions. It is not comparable ${ }^{3}$ with 270 million USD that American investors overpaid in 2007 for investing in index MF with higher commission (Choi et al., 2010) in absolute terms but it is several times larger, if we consider the proportion of MF industry in relation to other instruments (Tables 4 and 5) and to GDP. Russia is 64th out of 67 regarding the proportion of MF industry to the country's GDP (Abramov and Akshenseva, 2015).

Therefore, the next hypothesis is that the possible reason for the extreme outcomes of non-optimal index-investing in transition markets (e.g. Russia) may lie in the low level of index investing culture. It is probable that the lower the general index investing culture in a country, the more disadvantaged the

\footnotetext{
${ }^{2}$ http://www.nlu.ru/pifs-scha.htm?tab=tab $1 \&$ pageNo $=0 \& s=1$ $\& \mathrm{~b}=0 \&$ searchdate $=31.12 .2015 \& \mathrm{t}=\% \mathrm{CE} \& \mathrm{c}=\mathrm{all}$

${ }^{3} 1$ USD is 60 rubles (approximative average for 2015).
}

investors. This might result in the stock market industry being underdeveloped. My research into this is at the initial stage.

\section{Conclusion}

Despite the very low trade volume of ETF in the Russian market, these funds have become very popular in the MF industry. During the last two years (2014-2015), the funds that invest only in one preselected ETF have raised more money than any other fund category in Russia. However, if an investor buys shares of an ETF via a mutual fund rather than directly she overpays up to $36 \%$ of the invested capital for a 10-year horizon.

The standard or technical explanations for the Russian ETF puzzle are "search costs", "trust", "MF having additional services" and "the interdiction of buying foreign stock for none qualified investors". In addition, I formulated two other hypotheses for future research. First, it is possible that one reason that "helps" investors to make non-optimal choices is their predisposition to categorical thinking: individual investors put these funds of funds into the same category as actively managed funds, so the commission of 2-3\% does not raises any questions. Second, there is a possible link between the general index-investing culture of a country and the scale of various losses for individual investors (not caused by management failure to perform or by stock market fluctuations), and, eventually, the development of the stock market industry in a country.

\section{References}

Abramov, A., Akshenseva, K. 2015. The Determinants of mutual fund performance in Russia, Journal of Corporate Finance Research 34(2), 37-53.

Bergstresser, D., Chalmers, J., Tufano, P. 2009. Assessing the costs and benefits of brokers in the mutual fund industry, The Review of Financial Studies 22(10), 4129-4156.

Boldin, M., Cici, G. 2010. The index fund rationality paradox, Journal of Banking and Finance 34(1), 33-43.

Choi, J., Laibson, D., Madrian, B. 2010. Why does the law of one price fail? An experiment on Index Mutual Funds, The Review of Financial Studies 23(4), 1405-1432.

Collins, S. 2005. Are S\&P 500 index mutual funds commodities? Perspective 11(3), 1-12.

Elton, E., Gruber, M., Busse, J. 2004. Are investor rational: Choices among index funds? The Journal of Finance 59(1), 261-288.

Hortacsu, A., Syverson, C. 2004. Product differentiation, search costs, and competition in the mutual fund industry: A case 
study of S\&P 500 index funds, The Quarterly Journals of Economics 119(2), 403-456.

Kostovetsky, L. 2003. Index mutual funds and exchange traded funds. A comparison of two methods passive investment, Journal of Portfolio Management 29(4), 80-92.
Tarassov, E.B. 2017b. The index fund rationality paradox and categorical thinking, HSE Economic Journal, forthcoming. Tarassov, E.B. 2016. ETF: History, working mechanism, academic literature review and research perspectives, Journal of Corporate Finance Research 38(2), 89-108.

\section{Appendix 1}

Table A1

Open-end Russian mutual funds money inflow, (million rubles)

\begin{tabular}{lrrr}
\hline MF category & $2014+2015$ & 2014 & 2015 \\
\hline Equity & -12561 & -6973 & -5588 \\
Bonds & -30278 & -33985 & 3707 \\
Blended & 4942 & 1086 & 3856 \\
Money market & -444 & 597 & -1041 \\
Index & -1358 & -1116 & -242 \\
Fund of funds & 6176 & 5794 & 382 \\
\hline
\end{tabular}

Sources: National League of Management Companies, http://www.nlu.ru/pifs-privlechenie.htm1, February, 2016 


\section{Appendix 2}

Table A2

Funds of funds, Russia (NAV descending). February 2016

\begin{tabular}{|c|c|c|}
\hline No. & Funds of funds & ETF which the fund invests in \\
\hline 1 & Sberbank Biotechnology & iShares Nasdaq Biotechnology ETF \\
\hline 2 & Raiffeisen USA & SPDR S\&P 500 ETF TRUST \\
\hline 3 & Raiffeisen debt market developed countries & iShares 1-3 Year Credit Bond ETF \\
\hline 4 & Sberbank USA & SPDR S\&P 500 ETF TRUST \\
\hline 5 & Sberbank Gold & Power Shares DB Gold Fund \\
\hline 6 & Sberbank emerging markets & Vanguard emerging market ETF \\
\hline 7 & Raiffeisen Gold & Power Shares DB Gold Fund \\
\hline 8 & Sberbank Global debt market & iShares USD J.P. Morgan Emerging markets Bond UCITS ETF \\
\hline 9 & Raiffeisen Europe & iShares MSCI EMU ETF \\
\hline 10 & Sberbank Europe & iShares EURO Stoxx $50 \mathrm{ETF}$ \\
\hline 11 & Uralsib debt market developed countries & iShares iBoxx usd Inv Grade Corp BD \\
\hline 12 & Gazprombank Gold & Power Shares DB Gold Fund \\
\hline 13 & Gazprombank Food & Power Shares DB Agriculture Fund \\
\hline 14 & Uralsib emerging market debt & iShares USD J.P. Morgan Emerging MRKTS \\
\hline 15 & Russian Standard Gold & Power Shares DB Gold Fund \\
\hline 16 & Gazprombank Oil & Power Shares DB Oil Fund \\
\hline 17 & Promsvyaz global markets & - \\
\hline 18 & RGS - world technology & Power Shares QQQ Trust \\
\hline 19 & BCS - international funds & - \\
\hline 20 & TKB Gold & Power Shares DB Gold Fund \\
\hline 21 & Openbank Gold & Power Shares DB Gold Fund \\
\hline 22 & RGS Gold & Power Shares DB Gold Fund \\
\hline 23 & Gazprombank emerging markets & iShares MSCI emerging markets index fund \\
\hline 24 & GERFIN & - \\
\hline 25 & Uralsib Gold & Power Shares DB Gold Fund \\
\hline 26 & Openbank China & iShares Large Cap ETF \\
\hline 27 & Alfa capital Gold & - \\
\hline 28 & Openbank international real estate & SPDR Dow Jones Global Real Estate ETF \\
\hline 29 & Saving management Germany & iShares MSCI Germany ETF \\
\hline 30 & Kapital Gold & Power Shares DB Gold Fund \\
\hline 31 & Ingostach world markets & ETF MSCI WORLD INDEX UCITS ETF \\
\hline 32 & Openbank developed markets & iShares MSCI EAFE Index Fund \\
\hline 33 & Saving management - Asia & iShates MSCI All countries Asia ex Japan ETF \\
\hline 34 & Openbank USA & iShares S7P 100 Index Fund \\
\hline 35 & Gazprombank western Europe & SPDR EURO Stoxx 50 ETF \\
\hline 36 & Ingostrach Real Estate & Lyxor UCITS ETF FTSE EPRA/NAREIT GLOBAL DEVELOPED \\
\hline 37 & Uralsib global real estate & SPDR Dow Jones Global Real Estate ETF \\
\hline 38 & First fund of funds & - \\
\hline 39 & MDM world of funds & - \\
\hline 40 & Saving management debt developed markets & iShares iBoxx usd Inv Grade Corp BD \\
\hline 41 & Uralsib developed markets & iShares MSCI World \\
\hline 42 & RAB gold, silver, platinum & - \\
\hline 43 & Openbank emerging markets & iShares MSCI Emerging Markets Index Fund \\
\hline 44 & Uralsib global commodities & Power Shares DB Commodity Tracking Index Fund \\
\hline 45 & Openbank commoditiies & Power Shares DB Commodity Index Tracking Fund \\
\hline 46 & OLMA USA & iShares S\&P 500 Stock Index Fund \\
\hline 47 & Uralsib emerging markets & Vanguard FTSE Emerging Markets ETF \\
\hline 48 & OLMA Europe & iShares EURO Stoxx 50 (DE) \\
\hline 49 & OLMA Gold & Power Shares DB Gold Fund \\
\hline 50 & OLMA China & iShares FTSE/Xinhua China 25 Index Fund \\
\hline 51 & LandProfint Latin America & iShares Latin America 40 ETF \\
\hline
\end{tabular}

${ }^{a}$ Created by the author based on National League of Management Companies information. http://www.nlu.ru/pifs-scha.htm?tab= tab1\&pageNo=0\&s $=1 \& b=0 \&$ searchdate $=29.02 .2016 \& \mathrm{t}=$ all $\& \mathrm{c}=\% \mathrm{D} 4 \mathrm{February} 2016$ 
Appendix 3. Interviews: main results and key points from two experts who invested in the funds of funds

Table A3

Interviews: main results

\begin{tabular}{lll}
\hline & Interviewer & $\begin{array}{l}\text { Suggested as the main } \\
\text { hypotheses* }\end{array}$ \\
\hline 1 & Professor in economics & $\mathrm{H} 1$ \\
2 & Professor in economics & $\mathrm{H} 1$ \\
3 & Professor in finance & $\mathrm{H} 1$ \\
4 & Professor in finance & $\mathrm{H} 3$ \\
5 & Professor in finance & $\mathrm{H} 4$ \\
6 & Professor in finance & $\mathrm{H} 4$ \\
7 & Professor in cognitive psychology & $\mathrm{H} 5$ \\
8 & PhD student & $\mathrm{H} 4$ \\
9 & PhD student & $\mathrm{H} 4$ \\
10 & PhD student & $\mathrm{H} 1$ \\
11 & PhD student & $\mathrm{H} 1$ \\
12 & HNWI & $\mathrm{H} 1$ \\
13 & HNWI & $\mathrm{H} 2$ \\
14 & HNWI & $\mathrm{H} 2$ \\
15 & HNWI & $\mathrm{H} 2$ \\
\hline
\end{tabular}

*1. search costs; 2 . trust; 3 . MF having additional services; 4. the interdiction of investing in foreign stock if not obtained a qualified investor status (in Russia since 2015); 5. a predisposition to categorical thinking/stereotyping; 6 . a low level of index investing culture. 
Two of the experts (one economics professor with a western $\mathrm{PhD}$ and one $\mathrm{CEO}$ of a large Russian company) invested their money in a Russian MF which invests further in one preselected western ETF. On the question "why", the professor answered that he trusted the market. "It seemed to me that it was impossible that something would be wrong with the product if so many people invested already. Apparently, they analyzed it already. Overall, the market is effective. The prices of the service should be on the fair level as the market always bring them there." In addition, the professor knew what an ETF was and bought units of the MF that invested further in the ETF consciously. He analyzed the ways to buy an ETF in the USA but did not think to investigate the ways to buy it in Russia. The CEO of a large Russian company answered that he had been trusting Private Banking department of a leading foreign financial institution, based in Moscow, for more than 10 years, investing in the MF that they had been recommending. However, he was confused by the question whether a MF takes commission when an investor buys and holds its units. He did not know that a MF has commissions. On the other hand, he was aware that the bank might earn something when selling him the MF units. He admitted that he had no idea what an ETF was.

\section{Appendix 4}

Table A4a

Calculation of the cost differences between investing in the same ETF via a discount broker (Br) or via a MF), 3 million Rubles, December 2015

\begin{tabular}{|c|c|c|c|c|c|c|c|c|c|c|c|}
\hline Inves & 0,5 & 1 & 2 & 3 & 4 & 5 & 6 & 7 & 8 & 9 & 10 \\
\hline es & 000 & 00 & 000 & 6000 & 6000 & 6000 & 6000 & 6000 & 6000 & 6000 & 6000 \\
\hline a d a & 156000 & 126000 & 177000 & 258000 & 339000 & 420000 & 501000 & 582000 & 663000 & 744000 & 825000 \\
\hline $\begin{array}{l}\text { Via MF Sberbank via Citibank, } \\
\text { rubles }\end{array}$ & 208500 & 208500 & 289500 & 370500 & 451500 & 532500 & 613500 & 694500 & 775500 & 856500 & 937500 \\
\hline Jia MF Raiffeisenbank, rubles & 0 & 1 & & & 43 & 5 & & & 00 & 972 & 1080000 \\
\hline $\begin{array}{l}\text { Difference, } \mathrm{Br} \text { and MF Sberbank, } \\
\text { rubles }\end{array}$ & 150000 & 120000 & 171000 & 252000 & 333000 & 414000 & 495000 & 576000 & 657 & 738000 & 819000 \\
\hline Share (\%) of the capital invested & 5 & 4 & 0 & 8 & 11 & 14 & 17 & 19 & 22 & 25 & 27 \\
\hline $\begin{array}{l}\text { Difference, Br and Citibank, } \\
\text { rublees }\end{array}$ & 202500 & 202500 & 283500 & 364500 & 445500 & 526500 & 607500 & 688500 & 769500 & 850500 & 931500 \\
\hline 6) of the capital invested & 7 & 7 & 9 & 12 & 15 & 1 & 24 & 2 & & 28 & \\
\hline $\begin{array}{l}\text { Difference, } \mathrm{Br} \text { and Raiffeisen, } \\
\text { rubles }\end{array}$ & 162000 & 162000 & 240000 & 318000 & 426000 & 534000 & 642000 & 750000 & 858000 & 966000 & 1074000 \\
\hline Share (\%) of the capital invested & 5 & 5 & 8 & 11 & 14 & 18 & 21 & 25 & 29 & 32 & 36 \\
\hline
\end{tabular}


Table A4b

Expenses of investing in an ETF via a Sberbank or Raiffeisenbank MF and a Sberbank MF through Citibank, 3 million Rubles, December 2015

\begin{tabular}{|c|c|c|c|c|c|c|c|c|c|c|c|c|}
\hline Period (years) & & 0,5 & 1 & 2 & 3 & 4 & 5 & 6 & 7 & 8 & 9 & 10 \\
\hline Sberbank & $\%$ & & & & & & & & & & & \\
\hline Total & & 156000 & 126000 & 177000 & 258000 & 339000 & 420000 & 501000 & 582000 & 663000 & 744000 & 825000 \\
\hline management & 0,02 & 60000 & 60000 & 120000 & 180000 & 240000 & 300000 & 360000 & 420000 & 480000 & 540000 & 600000 \\
\hline custody/audit & 0,002 & 6000 & 6000 & 12000 & 18000 & 24000 & 30000 & 36000 & 42000 & 48000 & 54000 & 60000 \\
\hline other exp. & 0,005 & 15000 & 15000 & 30000 & 45000 & 60000 & 75000 & 90000 & 105000 & 120000 & 135000 & 150000 \\
\hline$<3$ million rubles & 0,01 & & & & & & & & & & & \\
\hline$>3$ million rubles & 0,005 & 15000 & 15000 & 15000 & 15000 & 15000 & 15000 & 15000 & 15000 & 15000 & 15000 & 15000 \\
\hline$<181$ days & 0,02 & 60000 & & & & & & & & & & \\
\hline$<732$ days & 0,01 & & 30000 & & & & & & & & & \\
\hline$>732$ days & 0 & & & & & & & & & & & \\
\hline \multicolumn{13}{|l|}{ Raiffeisenbank } \\
\hline Total & & 168000 & 168000 & 246000 & 324000 & 432000 & 540000 & 648000 & 756000 & 864000 & 972000 & 1080000 \\
\hline management & 0,024 & 72000 & 72000 & 144000 & 216000 & 288000 & 360000 & 432000 & 504000 & 576000 & 648000 & 720000 \\
\hline custody/audit & 0,006 & 18000 & 18000 & 36000 & 54000 & 72000 & 90000 & 108000 & 126000 & 144000 & 162000 & 180000 \\
\hline other exp. & 0,006 & 18000 & 18000 & 36000 & 54000 & 72000 & 90000 & 108000 & 126000 & 144000 & 162000 & 180000 \\
\hline$<730$ days & 0,02 & 60000 & 60000 & & & & & & & & & \\
\hline$<1095$ days & 0,01 & & & 30000 & & & & & & & & \\
\hline$>1095$ days & 0 & & & & & & & & & & & \\
\hline \multicolumn{13}{|l|}{ Citibank } \\
\hline Total & & 208500 & 208500 & 289500 & 370500 & 451500 & 532500 & 613500 & 694500 & 775500 & 856500 & 937500 \\
\hline management & 0,02 & 60000 & 60000 & 120000 & 180000 & 240000 & 300000 & 360000 & 420000 & 480000 & 540000 & 600000 \\
\hline custody/audit & 0,002 & 6000 & 6000 & 12000 & 18000 & 24000 & 30000 & 36000 & 42000 & 48000 & 54000 & 60000 \\
\hline other exp. & 0,005 & 15000 & 15000 & 30000 & 45000 & 60000 & 75000 & 90000 & 105000 & 120000 & 135000 & 150000 \\
\hline$<1$ million rubles & 0,015 & & & & & & & & & & & \\
\hline$<5$ million rubles & 0,0125 & 37500 & 37500 & 37500 & 37500 & 37500 & 37500 & 37500 & 37500 & 37500 & 37500 & 37500 \\
\hline$>5$ million rubles & 0,01 & & & & & & & & & & & \\
\hline To sell units & 0,03 & 90000 & 90000 & 90000 & 90000 & 90000 & 90000 & 90000 & 90000 & 90000 & 90000 & 90000 \\
\hline
\end{tabular}

